\title{
Rheological Behavior of Recycled Fiber Reinforced Self-Compacted Concrete with Recycled Coarse Aggregate
}

\author{
Shkar Latif ${ }^{1} \&$ Bayan S. Al-Numan ${ }^{2} \&$ Esamaddin Mulapeer ${ }^{3}$ \\ ${ }^{1,2 \& 3}$ Civil Engineering Department, Tishk International University, Erbil, Iraq \\ Correspondence: Bayan Salim Al-Nu'man, Tishk International University, Erbil, Iraq. \\ Email: bayan.salim@ishik.edu.iq
}

Doi: 10.23918/eajse.v6i1p17

\begin{abstract}
It is known that self-compacted concrete SCC is used to serve the construction of concrete structures with complicated shapes having congested reinforcements. Sustainable SCC is produced now by recycled concrete aggregates RCA from construction wastes. To improve the strength of this concrete, with a further eye on sustainability, recycled steel fibers RSF is utilized as reinforcing to the SCC. In this work, $12 \mathrm{SCC}$ mixes were prepared with different mixing proportions. Cement is replaced with $5 \%$ silica fume. RCA replacement percentages were $25 \%, 50 \%$, and $100 \%$ RCA. RSF was used with $0.50 \%, 0.75 \%$ by volume of concrete. The slump flow, J-Ring, and V-Funnel tests are performed to estimate the rheological behavior of all concrete mixtures. Results indicate that RCA/RSF SCC passed the slump flow, J-Ring tests, and overpassed V-Funnel test requirements satisfactorily.
\end{abstract}

Keywords: Self-Compacting Concrete, Recycled Aggregate (RCA), Recycled Steel Fiber (RSF), Silica Fume, And Fresh Properties

\section{Introduction}

The constructions of substantial concrete structures have been increased with designed complex forms and complicated reinforcements that make the workability of the fresh concrete to be unworkable and efficiently burdensome. Japanese scholars developed a new kind of concrete during $1980^{\text {th }}$, which is known as self-compacting concrete (SCC). SCC is one of the particular types which without mechanical vibrating, attains compaction. During its plastic state flowing under its weight and protects, it is homogeneousness throughout filling every form like the framework's congested reinforcement (Revathi, Selvi, \& Velin, 2013). A massive quantity of construction wastes produced annually from demolished buildings, earthquakes, natural disasters, construction places, materials of construction, and factories of materials (Al-Numan, 2019/12; Revathi et al., 2013; Younis \& Latif; Younis \& Pilakoutas, 2013).

Because of inadequate removal sites, especially around big cities for eliminating and removing the wastes, a significant problem occurs. In contrast, utilizing natural concrete aggregate is increased too much due to urging construction activity owing to the fast growth of urbanization. Similarly, to overcome this problem in the construction industry, constructing sustainable concrete needs to be considered. So the researchers practiced a sustainable technique to achieve an innovative concrete kind by using the demolished waste of construction efficiently. Recycling and utilizing the concrete wastes is very significant in nature protection since it can reduce the environment pollution and protects nature by decreasing the usage of natural aggregate resources (Omrane, Kenai, Kadri, \& Ait-Mokhtar, 2017). However the fresh property of the concrete is affected negatively by utilizing recycled concrete aggregate since the slump loss of RCA is more than the NCA (Abed \& Nemes, 2019; CarroYLópez et 
al., 2017; Debieb, Courard, Kenai, \& Degeimbre, 2009; Hama \& Hilal, 2017); generally, this is because of the shape, size, water content and texture of the RCA that influenced profoundly on the fresh property of the concrete (Abed \& Nemes, 2019; Itsubo, Sakagami, Washida, Kokubu, \& Inaba, 2004; Purushothaman \& Mani, 2014; Revathi et al., 2013).

On the other hand, in order to improve the strength of the concrete, scholars try to use many types of fibers for commercial applications and reinforcement of concrete; usually, some of them are existing. Steel, polypropylene, natural cellulose, nylon, carbon, and glass are some kinds of fibers (Mermerdaş, Mulapeer, \& Oleiwi, 2019). Several fiber types are available to be used in concrete reinforcement. Besides their sources, they have different mechanical properties, density, geometry, and shape. Apart from steel fiber, glass and polypropylene are the most used fiber types. Steel is the most used structural fibers in the construction industry. They have different shapes, performance levels, and geometries. There most common steel fiber geometries are straight, hooked, deformed, and coned end.

The attention of the researchers attracted to use recycled steel fiber instead of fabricated steel fiber as a reinforcement matrix in cement base materials over the last decade, regarding the high cost of steel fiber, and it is friendly to the environment (Mastali \& Dalvand, 2016). From the results of the fresh tests, usually, the passing ability and flowability of the fresh concrete are significantly reduced by adding RSF of scraped tires. Generally, the fresh properties of concrete reduced gradually by using RSF. The length and amount of RSF affect the fresh property of the SCC (Younis, Ahmed, \& Najim, 2018). By increasing the amount of RSF, the flowability is decreased, as shown from the results of Simalti and Singh (2019) and a similar outcome attained by (Groli, Pérez Caldentey, \& Soto, 2014; Mastali \& Dalvand, 2016, 2017). The workability and homogeneity of the fresh concrete are inversely proportional to the amount of RSF(Liew \& Akbar, 2020). This study investigates the influence of utilizing both RCA and RSF on fresh properties of SCC, like flowability, passing ability, and viscosity of the fresh concrete by Slump Flow, J-Ring, and V-Funnel test.

\section{Experimental Details}

\subsection{Materials}

The materials used in this research are (cement, silica fume (SF), natural concrete aggregate (NCA), recycled coarse aggregate (RCA), natural fine aggregate (NFA), recycled steel fiber (RSF), water and superplasticizer. Ordinary Portland cement (OPC) type CEM I 42.5 R is used. Silica fume is also used by replacement of $5 \%$ of cement. The physical properties and the chemical compositions of the cement and the silica fume are included in Tables 1 and 2, respectively. 
Table 1: Chemical composition and physical properties of Cement

\begin{tabular}{|l|c|}
\hline Chemical compositions \% & CEM I 42.5 R \\
\hline $\mathrm{CaO}$ & 67.46 \\
\hline $\mathrm{SiO}_{2}$ & 13.48 \\
\hline $\mathrm{Al}_{2} \mathrm{O}_{3}$ & 3.69 \\
\hline $\mathrm{Fe}_{2} \mathrm{O}_{3}$ & 7.78 \\
\hline $\mathrm{MgO}$ & 1.29 \\
\hline $\mathrm{Na}_{2} \mathrm{O}$ & 0.36 \\
\hline $\mathrm{K}_{2} \mathrm{O}$ & 0.98 \\
\hline $\mathrm{SO}_{3}$ & 4.82 \\
\hline $\mathrm{Physical}$ Properties & CEM I 42.5 R \\
\hline Specific Weight $(\mathrm{g} / \mathrm{m} 3)$ & 3.18 \\
\hline Specific surface area (Blaine $(\mathrm{cm} 2 / \mathrm{g})$ & 3352 \\
\hline Loss on ignition & 1.98 \\
\hline
\end{tabular}

Table 2: Chemical composition and physical properties of Silica Fume

\begin{tabular}{|l|c|}
\hline Chemical compositions \% & Silica Fume \\
\hline $\mathrm{CaO}$ & 1.6 \\
\hline $\mathrm{SiO}_{2}$ & 92.3 \\
\hline $\mathrm{Al}_{2} \mathrm{O}_{3}$ & 1.3 \\
\hline $\mathrm{Fe}_{2} \mathrm{O}_{3}$ & 1 \\
\hline $\mathrm{MgO}$ & 0.9 \\
\hline $\mathrm{Na}_{2} \mathrm{O}$ & 0.25 \\
\hline $\mathrm{K}_{2} \mathrm{O}$ & 0.79 \\
\hline $\mathrm{SO}_{3}$ & 0.11 \\
\hline Specific Weight $\left(\mathrm{g} / \mathrm{m}^{3}\right)$ & 2.2 \\
\hline Specific surface area $\left(\right.$ Blaine $\left(\mathrm{cm}^{2} / \mathrm{g}\right)$ & 21 \\
\hline Loss on ignition & 1.53 \\
\hline
\end{tabular}

River natural fine aggregate and coarse aggregate of having a specific gravity of 2.67 and 2.65 , respectively, are used. The natural coarse aggregate is replaced by recycled coarse aggregate with $25 \%$, $50 \%$, and $100 \%$. The RCA is obtained from a demolished reinforced concrete building in Erbil. The samples were taken from a slab of the demolished building; after that, the slab is broken for smaller pieces, not more than $25 \mathrm{~mm}$ in size. The RCA is sieved with (No. 5/8), the passed RCA is used. The Chemical composition and physical properties of NCA, RCA, and NFA are listed in Tables 3 and 4, respectively.

Table 3: Physical properties of Aggregates

\begin{tabular}{|l|c|c|c|}
\hline Physical Properties & CA & NA & RCA \\
\hline Fines Modulus & 6.6 & 2.55 & 6 \\
\hline Specific gravity $\left(\mathrm{g} / \mathrm{m}^{3}\right)$ & 2.64 & 2.52 & 2.5 \\
\hline Water absorption $(\%)$ & 0.4 & 0.25 & 3 \\
\hline
\end{tabular}


The RSF is obtained from consumed old tires; by pyrolysis process the steel fiber has been extracted out from the tire. The physical properties of the RSF are listed in Table 4.

Table 4: Physical properties of recycled steel fibers

\begin{tabular}{|l|c|}
\hline Physical Properties & RSF \\
\hline Diameter $(\mathrm{mm})$ & 0.3 \\
\hline Length $(\mathrm{mm})$ & $10.0-20.0$ \\
\hline Specific gravity & 7.8 \\
\hline
\end{tabular}

For increasing the workability, high-performance concrete superplasticizer (Formerly known as Flocrete PC200) is used. The chemical and physical properties are listed in Table 5.

Table 5: Chemical compositions and physical properties of superplasticizer

\begin{tabular}{|l|l|}
\hline Chemical compositions and Physical Properties & Superplasticizer \\
\hline Form & Liquid \\
\hline Color & Light Yellow \\
\hline Odor & Slight/Faint \\
\hline Boiling Point (C) & $>100$ \\
\hline Flash Point (closed up) (C) & None \\
\hline Autoflamibilty & None \\
\hline Explosive Properties \% & None \\
\hline Freezing point & -3 \\
\hline Relative Density & $1.03-1.07$ \\
\hline Water Solubility & Soluble \\
\hline
\end{tabular}

\subsection{Mixture Proportions}

Twelve mixes were prepared with different mixing proportions. The first mix is a control mix without RCA and RSF, and the second one is $25 \%$ RCA, the third one with $50 \%$ RCA, and the fourth one with $100 \%$ RCA. From the $5^{\text {th }}$ through the $8^{\text {th }}$ mix, $(0.5 \%)$ RSF was used constantly with $25 \%, 50 \%$, and $100 \%$ RCA, and from the $9^{\text {th }}$ mix through the $12^{\text {th }}(0.75 \%)$ RSF constantly used with $25 \%, 50 \%$ and $100 \%$ RCA. Table 6 includes details of all mixes.

Table 6: Mixture proportions $\left(\mathrm{kg} / \mathrm{m}^{3}\right)$

\begin{tabular}{|l|c|c|c|c|c|c|c|c|c|c|c|c|}
\hline Mixes & M1 & M2 & M3 & M4 & M5 & M6 & M7 & M8 & M9 & M10 & M11 & M12 \\
\hline C & 475 & 475 & 475 & 475 & 475 & 475 & 475 & 475 & 475 & 475 & 475 & 475 \\
\hline SF & 25 & 25 & 25 & 25 & 25 & 25 & 25 & 25 & 25 & 25 & 25 & 25 \\
\hline W & 150 & 150 & 150 & 150 & 150 & 150 & 150 & 150 & 150 & 150 & 150 & 150 \\
\hline SP & 15 & 15 & 15 & 15 & 15 & 15 & 15 & 15 & 15 & 15 & 15 & 15 \\
\hline RSF & 0 & 0 & 0 & 0 & 39 & 39 & 39 & 39 & 59 & 59 & 59 & 59 \\
\hline NCA & 810 & 607 & 405 & 0 & 804 & 603 & 402 & 0 & 801 & 600 & 400 & 0 \\
\hline RCA & 0 & 196 & 391 & 782 & 0 & 194 & 388 & 777 & 0 & 193 & 387 & 774 \\
\hline FA & 982 & 982 & 982 & 982 & 975 & 975 & 975 & 975 & 971 & 971 & 971 & 971 \\
\hline
\end{tabular}


C: Cement, SF: silica Fume, W: Water, SP: superplasticizer, RSF: recycled steel Fiber, NCA: normal concrete Aggregate, RCA: recycled concrete aggregate, FA: fine aggregate.

\subsection{Specimens Casting and Curing}

One hundred forty-two samples were prepared for twelve different mixes. From each mix, six cubes with size $(100 \times 100 \times 100) \mathrm{mm}$ and six prisms with size $(100 \times 100 \times 500) \mathrm{mm}$ were prepared. Fresh properties tests such as Slump Flow, J-Ring, and V-Funnel were performed for all the mixes.

\subsection{Test Methods}

\subsubsection{Slump Flow, J-Ring and V-Funnel}

Slump flow is used to evaluate the flowability and deformability of fresh properties of all the mixes of concrete. ASTM C 1611 is used to achieve the slump flow. For designing the self-compacting concrete mixes, the acceptance rate is between (500 to 750 ) $\mathrm{mm}$, as stated by BIBM and ERMCO (2005). The passing ability of the self-compacting concrete through obstacles is measured by using the J-Ring test method. ASTM (C1621/C 1621M-09) is used to perform the test, as mentioned in BIBM and ERMCO (2005). The filling ability and flowability of the fresh properties of Self-compacting concrete are measured by using the $\mathrm{V}$-funnel test. The test is achieved by measuring the period of passing fresh self-compacting concrete through an opening that narrowed at the end of the v-funnel. The period required for the test is between (8-25) seconds, as described by EFNARC (BIBM \& ERMCO, 2005). The test apparatus of Slump flow, J-Ring, and V- funnel is shown in Figure 1.

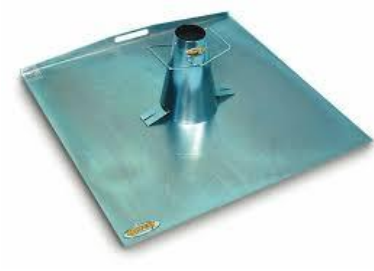

(a) Slump Flow(matest, 2017)

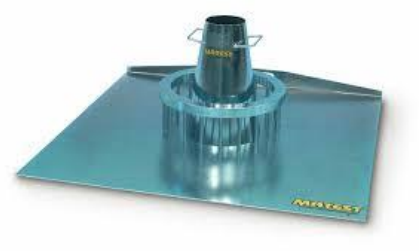

(b) J-Ring(matest, 2017)

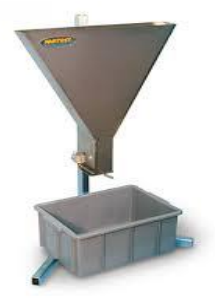

(c) V funnel(matest, 2017)

Figure 1: The test apparatus 


\section{Results and Discussion}

Table 7 shows all the results of fresh properties.

Table 7: Test results for various SCC mixes

\begin{tabular}{|c|c|c|c|}
\hline Mixes & $\begin{array}{c}\text { Slump Flow } \\
(\mathrm{mm})\end{array}$ & $\begin{array}{c}\text { J-Ring } \\
(\mathrm{mm})\end{array}$ & $\begin{array}{c}\text { V-Funnel } \\
(\text { Second })\end{array}$ \\
\hline M1(NCAScc) & 725 & 715 & 9 \\
\hline M2(RCA1Scc) & 705 & 685 & 11 \\
\hline M3(RCA2Scc) & 665 & 655 & 11.5 \\
\hline M4(RCA3Scc) & 655 & 650 & 12 \\
\hline M5(RSF0.5NCAScc) & 680 & 655 & 11 \\
\hline M6(RSF0.5RCA1Scc) & 675 & 650 & 17 \\
\hline M7(RSF0.5RCA2Scc) & 655 & 575 & 32 \\
\hline M8(RSF0.5RCA3Scc) & 645 & 555 & 38 \\
\hline M9(RSF0.75NCAScc) & 675 & 650 & 11.5 \\
\hline M10(RSF0.75RCA1Scc) & 650 & 575 & 24 \\
\hline M11(RSF0.75RCA2Scc) & 635 & 570 & 34 \\
\hline M12(RSF0.75RCA3Scc) & 620 & 510 & 40 \\
\hline
\end{tabular}

Scc: Self-compacting concrete, NCA: Natural concrete aggregate, RCA: Recycled concrete aggregate: 1 for $25 \%, 2$ for $50 \%, 3$ for $100 \%$ replacement, RSF: recycled steel fiber: 1 for $0.5 \%, 2$ for $0.75 \%$ by volume.

\subsection{Slump Flow Results}

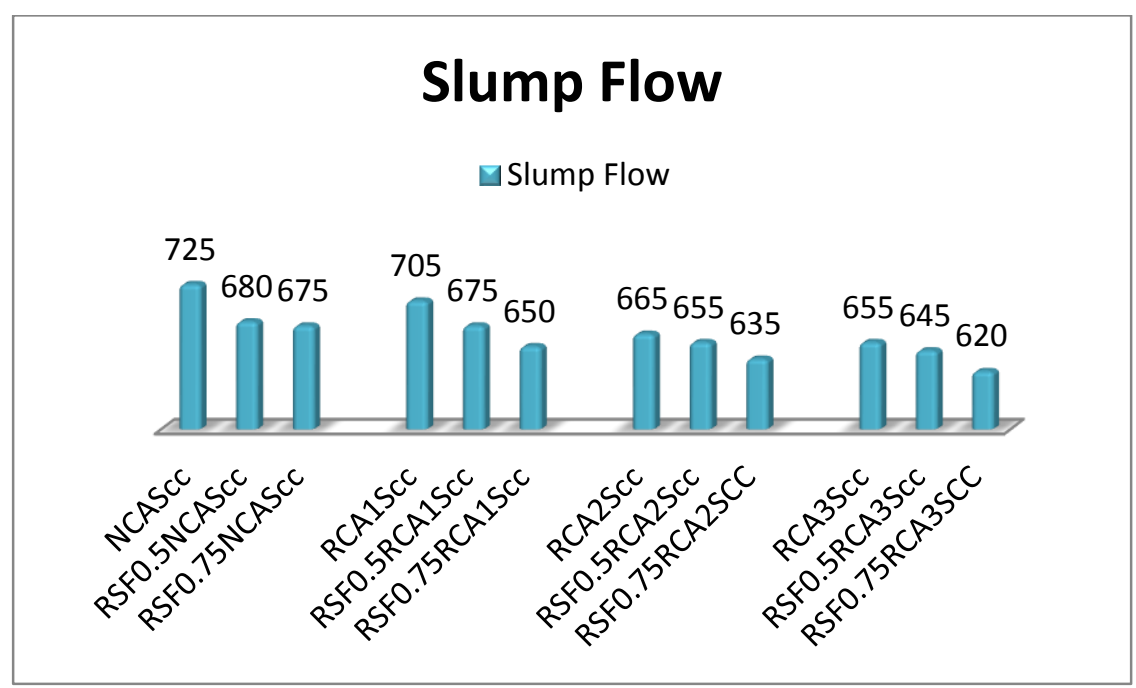

Figure 2: Slump flow results $(\mathrm{mm})$

As shown in figure 2, the slump flows of all mixes satisfy the SCC requirements. Although variation is indicated as shown in the results, the flowability of the control mix is more than rest mixes. As it is 
seen from the results, the slump flow for the first mix in which no RCA and RSF used is $725 \mathrm{~mm}$. As the RCA replacement and/or RSF percentages are increased, the slump flow is reduced. The last mix with $0.75 \%$ RSF and $100 \%$ RCA used slump flow reduced to $620 \mathrm{~mm}$; however, all the mixes are within the acceptable range. This was confirmed by (Omrane et al., 2017; Safiuddin, Salam, \& Jumaat, 2011; Silva, Robayo, Mattey, \& Delvasto, 2016) for RCA replacement. It can be explained that the angular shape and rough surface of the RCA opposite to the NCA are affecting the behavior (Abed \& Nemes, 2019; Mathew, 2015). Also, the water absorption of RCA is more than that of NCA, which can be considered as an effective factor.

It can be added that when introducing RSF to the SCC/RCA mixes, the slump flow is reduced further.(Younis et al., 2018). For instant, in the fifth and the ninth mixes in which fully NCA is used with $0.5 \%$ and $0.75 \%$ of RSF, the slump flow became $680 \mathrm{~mm}$ and $675 \mathrm{~mm}$, respectively, which are less than the first mix. For the last three mixes in which $0.75 \%$ RSF is used with $25 \%, 50 \%$, and $100 \%$ RCA, the flowability decreased to $650 \mathrm{~mm}, 635 \mathrm{~mm}$, and $620 \mathrm{~mm}$, respectively.

\subsection{J-Ring Results}

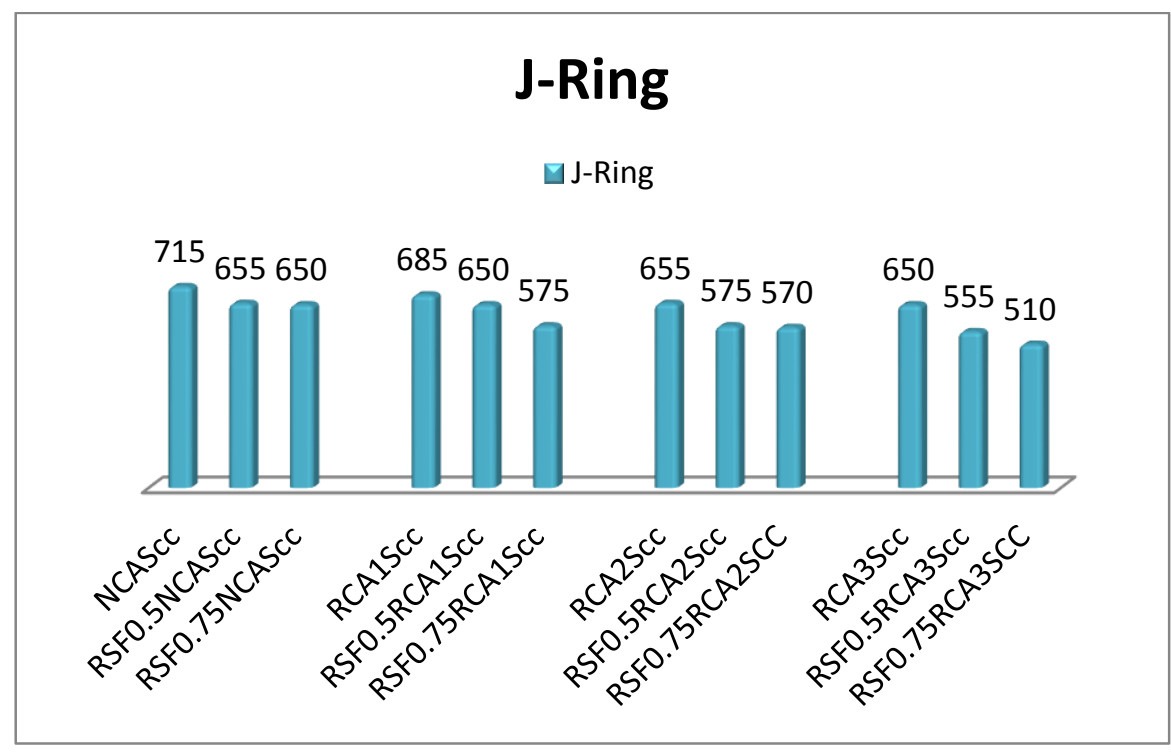

Figure 3: J-Ring results (mm)

Figure 3 shows that the passing ability from J-Ring tests of all mixes satisfies the SCC requirements. The control mix shows the greatest passing ability over the rest of the mixes. By increasing the percentage of RCA, the passing ability is reduced. This is as confirmed by Safiuddin et al. (2011). Same as the slump flow results -as it is shown in figure 3- all the mixes are in the range of SCC in which they record passing ability $715 \mathrm{~mm}$ to $510 \mathrm{~mm}$. After replacing NCA by RCA with $25 \%, 50 \%$, and $100 \%$ for $2^{\text {nd }}, 3 \mathrm{rd}$, and 4 th mixes, the passing ability reduced to $685 \mathrm{~mm}, 655 \mathrm{~mm}$, and $650 \mathrm{~mm}$, respectively.

It can be added hereby that by introducing RSF to the SCC mixes, the passing ability is reduced. From the $5^{\text {th }}$ through the $8^{\text {th }}$ mix after adding $0.5 \%$ RSF, the passing ability decreased more due to the effectiveness of the RSF as follows $655 \mathrm{~mm}, 650,575 \mathrm{~mm}$, and $550 \mathrm{~mm}$ corresponding to RCA with $0 \%, 25 \%, 50 \%$, and $100 \%$. Moreover, with $0.75 \% \mathrm{RSF}$, in the last four mixes, the less passing ability was recorded, which is a reduction from $650 \mathrm{~mm}$ to $510 \mathrm{~mm}$, see figure 3 . 


\subsection{V-Funnel Results}

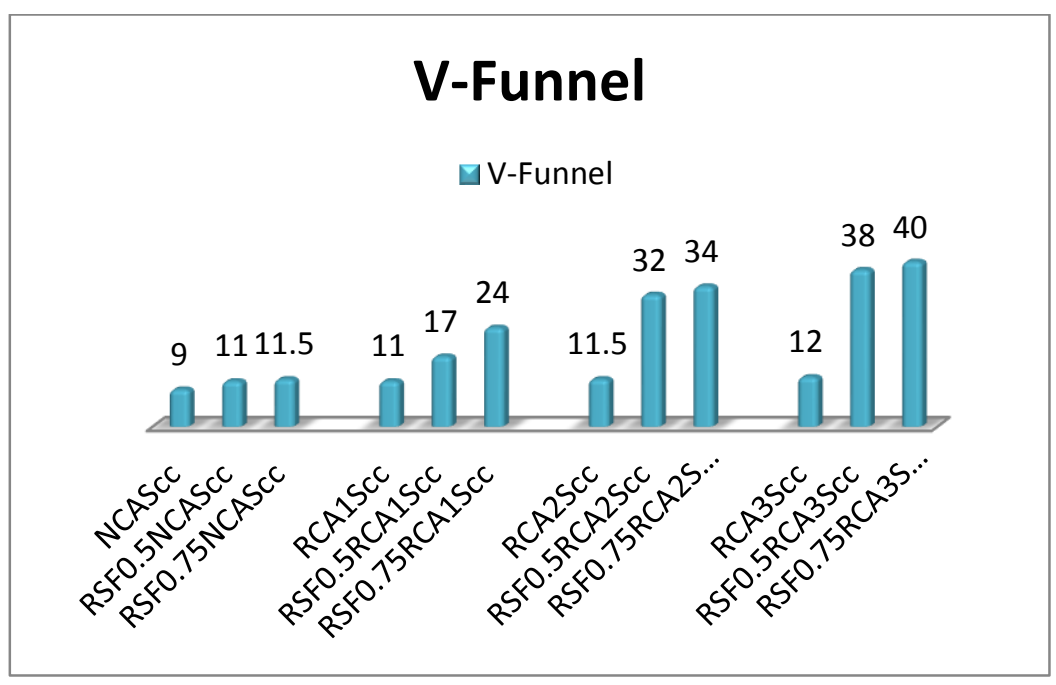

Figure 4: V-Funnel results (second)

For the V-funnel test, the first four mixes results satisfy the requirements for SCC, which is in-between 8-25 seconds, as indicated by BIBM and ERMCO (2005). In the first mix, the period for the test is 9 seconds. After Replacing NCA by RCA by $25 \%, 50 \%$, and $100 \%$, the time is increased to $11,11.5,12$ seconds, respectively, which remained within the standard range. Adding $0.5 \%$ RSF to ordinary concrete increases further the period from 11 to 17 seconds (see fifth and sixth mixes); the time increases from 11 to 17 seconds; however, it remains within the standard time. When replacing RCA with $50 \%$ and $100 \%$, the time is increased to 32 and 38 seconds, which passes the range and does not satisfy SCC requirements.

With $0.75 \%$ of RSF (see $9^{\text {th }}$ and $10^{\text {th }}$ mixes), the time is increased from 11.5 to 24 seconds, however, still within the range. On the other hand, with the replacement of RCA to 50\% and more, time reaches 34 and 40 seconds, which passes the range. It indicates that using both RCA and RSF together considerably affects flowability in which both of them together increases the viscosity and make an obstacle for the flowability. However, it can be argued that the V-Funnel test is inherently not suitable for this type of concrete, and it suffices to use slump flow and J-ring tests.

\section{Conclusion}

Sustainable SCC with RCA partially or fully replacing NCA and reinforced with RSF is produced in this work and tested for rheological behavior. From the results, the following conclusions can be drawn.

1. SCC passed the flow test, J-ring test, and the V-Funnel test. All values were within the acceptable limits.

2. Replacing NCA by RCA partially or fully in the SCC caused a decrease in all flow values. The entirely replaced RCA yields the lowest flow values. However, all values remain within acceptable limits.

3. Adding RSF to SCC decreased the flow values; the $0.75 \%$ by volume mixes yields the lowest flow result. 
4. Utilizing both RCA and RSF shows a further decrease in inflow for all tests. However, all values remain within the acceptable limits, except the V-Funnel test result for $50 \%$ or fully replaced RCA together with the RSF.

5. It can be argued that the V-Funnel test is inherently not suitable for this type of concrete, and it suffices to use slump flow and J-ring tests.

\section{References}

Abed, M., \& Nemes, R. (2019). Fresh properties of the self-compacting high-performance concrete using recycled concrete aggregate. Építöanyag (Online)(1), 18-23.

Al-Numan, B. S., Razhan Shahab Ahmed. (2019/12). Investigation on Fresh Properties of Concrete Made with Recycled Lightweight Aggregates from Demolished Bricks. Eurasian Journal of Science \& Engineering, 5(1), 48 - 55.

Bibm, C., \& Ermco, E. (2005). EFNARC (2005) The European guidelines for self-compacting concrete. Specification, Production and Use.

CarroYLópez, D., GonzálezYFonteboa, B., MartínezYAbella, F., GonzálezYTaboada, I., de Britob, J., \& VarelaYPugaa, F. (2017). Proportioning, microstructure and fresh properties of selfYcompacting concrete with recycled sand. Procedia Engineering, 171, 645-657.

Debieb, F., Courard, L., Kenai, S., \& Degeimbre, R. (2009). Roller compacted concrete with contaminated recycled aggregates. Construction and Building Materials, 23(11), 33823387.

Groli, G., Pérez Caldentey, A., \& Soto, A. G. (2014). Cracking performance of SCC reinforced with recycled fibres-an experimental study. Structural Concrete, 15(2), 136-153.

Hama, S. M., \& Hilal, N. N. (2017). Fresh properties of self-compacting concrete with plastic waste as partial replacement of sand. International Journal of Sustainable Built Environment, 6(2), 299-308.

Itsubo, N., Sakagami, M., Washida, T., Kokubu, K., \& Inaba, A. (2004). Weighting across safeguard subjects for LCIA through the application of conjoint analysis. The International Journal of Life Cycle Assessment, 9(3), 196-205.

Liew, K., \& Akbar, A. (2020). The recent progress of recycled steel fiber reinforced concrete. Construction and Building Materials, 232, 117232.

Mastali, M., \& Dalvand, A. (2016). Use of silica fume and recycled steel fibers in self-compacting concrete (SCC). Construction and Building Materials, 125, 196-209.

Mastali, M., \& Dalvand, A. (2017). Fresh and hardened properties of self-compacting concrete reinforced with hybrid recycled steel-polypropylene fiber. Journal of Materials in Civil Engineering, 29(6), 04017012.

Matest. (2017). SCC Testing Apparatus. Retrieved from http://www.matest.com/en/concretetesting-equipment/scc-testing-apparatus/

Mathew, A. V. P. (2015). A study on the self compacting properties of recycled concrete incorporating a new mix proportioning method.

Mermerdaş, K., Mulapeer, E. S., \& Oleiwi, S. M. (2019). Effect of glass fiber addition on the strength properties and pore structure of fly ash based Geopolymer composites. Eskişehir Technical University Journal of Science and Technology A-Applied Sciences and Engineering, 20(4), 427-435.

Omrane, M., Kenai, S., Kadri, E.-H., \& Aït-Mokhtar, A. (2017). Performance and durability of self compacting concrete using recycled concrete aggregates and natural pozzolan. Journal of Cleaner Production, 165, 415-430.

Purushothaman, R., \& Mani, S. (2014). Studies on fresh and hardened properties of recycled aggregate concrete with quarry dust. ACI Materials Journal, 111(3).

Revathi, P., Selvi, R., \& Velin, S. (2013). Investigations on fresh and hardened properties of recycled aggregate self compacting concrete. Journal of the Institution of Engineers (India): Series A, 94(3), 179-185. 
Safiuddin, M., Salam, M., \& Jumaat, M. Z. (2011). Effects of recycled concrete aggregate on the fresh properties of self-consolidating concrete. Archives of Civil and Mechanical Engineering, 11(4), 1023-1041.

Silva, Y. F., Robayo, R. A., Mattey, P. E., \& Delvasto, S. (2016). Properties of self-compacting concrete on fresh and hardened with residue of masonry and recycled concrete. Construction and Building Materials, 124, 639-644.

Simalti, A., \& Singh, A. (2019). Mix proportioning of recycled steel fiber reinforced self compacting concrete. Paper presented at the Proceeding of International UKIERI Concrete Congress.

Younis, K. H., Ahmed, F. S., \& Najim, K. B. (2018). Self-Compacting Concrete Reinforced with Steel Fibers from Scrap Tires: Rheological and Mechanical Properties. Paper presented at the Int. Eng. Conf.

Younis, K. H., \& Latif, S. Mechanical performance of self-compacting concrete incorporating recycled aggregate: A.

Younis, K. H., \& Pilakoutas, K. (2013). Strength prediction model and methods for improving recycled aggregate concrete. Construction and Building Materials, 49, 688-701. 